\title{
Evaluation of biopsies of oral and maxillofacial lesions: a retrospective study
}

\author{
Hatice Hosgor ${ }^{1}$, Berkay Tokuc ${ }^{1}$, Bahadır Kan², Fatih Mehmet Coskunses ${ }^{1}$ \\ ${ }^{\prime}$ Department of Oral and Maxillofacial Surgery, Faculty of Dentistry, Kocaeli University, Kocaeli, \\ ${ }^{2}$ Private Clinic, Kocaeli, Turkey
}

\begin{abstract}
J Korean Assoc Oral Maxillofac Surg 2019;45:316-323)
Objectives: This study aimed to determine the prevalence of odontogenic cysts, tumors, and other lesions among reports in the archives of the Department of Oral and Maxillofacial Surgery at the Faculty of Dentistry affiliated with Kocaeli University collected over a four-year period.

Materials and Methods: In this retrospective study, patient records from the archive of the Department of Oral and Maxillofacial Surgery from 2014 to 2018 were reviewed. Patient demographic information (age and sex) and lesion location were recorded and analyzed.

Results: From a total of 475 files reviewed, odontogenic cyst was confirmed in 340 cases (71.6\%), and odontogenic tumor was confirmed in 52 cases (10.9\%). Regarding odontogenic cyst type, the most common was radicular cyst (216 cases), followed by dentigerous cyst (77 cases) and odontogenic keratocyst (23 cases). Among odontogenic tumors, the most frequent was odontoma (19 cases), followed by ossifying fibroma (18 cases) and ameloblastoma ( 9 cases). Giant cell granuloma was also reported in 35 cases.

Conclusion: The distribution pattern of odontogenic cysts and tumors in our retrospective study is relatively similar to that reported in the literature. Complete clinical reports for final diagnosis of these lesions and routine follow-up examinations are very important for treatment.
\end{abstract}

Key words: Odontogenic cysts, Odontogenic tumors, Jaw neoplasms

[paper submitted 2019. 2. 4 / revised 1st 2019. 3. 16, 2nd 2019. 3. 30 / accepted 2019. 4. 16]

\section{Introduction}

A large variety of lesions can affect the oral and maxillofacial (OMF) region including those related to inflammatory processes and malignant neoplasms ${ }^{1}$. The clinical manifestations of these lesions comprise pain, paresthesia, swelling, drainage, tooth loss, root resorption, and facial deformity ${ }^{2}$. Changes in OMF tissues of these lesions may cause aesthetically and functionally unfavorable effects in the patients, so a careful clinical and radiological examination for correct diagnosis and treatment planning in addition to histopathological examination of biopsy samples are of great importance.

The first international classification system was published

\footnotetext{
Hatice Hosgor

Department of Oral and Maxillofacial Surgery, Faculty of Dentistry, Kocaeli University, Basiskele, Kocaeli 41190, Turkey

TEL: +90-262-344-22-22 FAX: +90-262-344-21-09

E-mail:drhaticehosgor@yahoo.com

ORCID: https://orcid.org/0000-0002-6925-9526

(c) This is an open-access article distributed under the terms of the Creative Commons Attribution Non-Commercial License (http://creativecommons.org/ licenses/by-nc/4.0/), which permits unrestricted non-commercial use, distribution, and reproduction in any medium, provided the original work is properly cited.

Copyright (C) 2019 The Korean Association of Oral and Maxillofacial Surgeons. All rights reserved.
}

in 1971 by the World Health Organization (WHO), covering odontogenic tumors, jaw cysts, and allied lesions. Subsequently, the classification was updated in 1992, 2005, and $2017^{3}$. In the latest edition of the classification scheme, lesions are classified by nature and biological behavior, and this classification has been accepted as a system that includes all odontogenic tissue lesions. According to the fourth edition, OMF lesions are classified into three groups of odontogenic cysts, odontogenic tumors, and bone tumors and related lesions ${ }^{4}$.

This study aimed to determine the frequency of odontogenic cysts, tumors, and other lesions and the demographic profile of affected patients as obtained from the archives of the Department of Oral and Maxillofacial Surgery at the Faculty of Dentistry affiliated with Kocaeli University (Kocaeli, Turkey) collected over a four-year period.

\section{Materials and Methods}

This retrospective study involved 475 individuals (287 males and 188 females) aged 87 to 88 years who were referred to Department of Oral and Maxillofacial Surgery, Faculty of Dentistry, Kocaeli University. In this study, patient 
records of histopathological reports from the archives of the Department of Oral and Maxillofacial Surgery from 2014 to 2018 were reviewed.

OMF lesions were classified into four groups of (1) odontogenic cysts, (2) odontogenic tumors, and (3) bone tumors and related lesions per the fourth edition of the WHO classification and (4) malignancies. Patient demographic information (age and sex) and anatomical location of the lesion were recorded and analyzed. The involved sites were subclassified into four regions: maxillary anterior, maxillary posterior, mandibular anterior, and mandibular posterior. In the context of recurrent lesions, only the first diagnosis was included in this study. The research protocol was approved by the Clinical Research Ethics Committee of Kocaeli University (KÜ GOKAEK 2018/151).

Data were analyzed using IBM SPSS Statistics (ver. 24.0; IBM, Armonk, NY, USA). The analyses were conducted at a $95 \%$ confidence level. A $P$-value less than 0.05 was considered statistically significant.

\section{Results}

A total of 475 oral biopsies was located among the archived records. Of these, 287 cases were diagnosed in males (60.4\%) and 188 cases were diagnosed in females $(39.6 \%)$. The distribution of the groups by sex and the statistical significance are shown in Table 1.

The mean age of all patients was $39.78 \pm 16.7$ years (range, 7-88 years). The age distribution and statistical values of the groups are presented in Table 2.

Of the 475 cases, 251 cases $(52.8 \%)$ occurred in the mandible and 224 cases (47.2\%) in the maxilla. The location distribution of pathologies according to group and associated statistical values are shown in Table 3 .

The group distributions were as follows: group $1(\mathrm{n}=340$; $71.6 \%)$, group $2(n=52 ; 10.9 \%)$, group $3(n=75 ; 15.8 \%)$, and group $4(\mathrm{n}=8 ; 1.7 \%)$. Among all lesions, radicular cysts $(\mathrm{n}=216 ; 45.5 \%)$ were the most common biopsied lesion, followed by dentigerous cysts $(n=77 ; 16.2 \%)$, giant cell granulomas $(n=35 ; 7.4 \%)$, and odontogenic keratocysts $(n=23 ; 4.8 \%)$.

Within group $1,216(63.5 \%)$ of the 340 cases were of radicular cyst, followed by 77 cases $(22.6 \%)$ of dentigerous

Table 1. Distributions of groups by sex

\begin{tabular}{|c|c|c|c|c|c|}
\hline & Lesion & Female & Male & Total & $P$-value \\
\hline \multirow[t]{6}{*}{ Group 1} & Radicular cyst & $73(33.8)$ & $143(66.2)$ & $216(100)$ & 0.064 \\
\hline & Dentigerous cyst & $21(27.3)$ & $56(72.7)$ & $77(100)$ & 0.512 \\
\hline & Odontogenic keratocyst & $6(26.1)$ & $17(73.9)$ & $23(100)$ & 0.649 \\
\hline & Nasopalatine duct cyst & $3(13.6)$ & $19(86.4)$ & $22(100)$ & 0.079 \\
\hline & Lateral periodontal cyst & $0(0)$ & $2(100)$ & $2(100)$ & 0.350 \\
\hline & Total & $103(30.3)$ & $237(69.7)$ & $340(100)$ & 0.236 \\
\hline \multirow[t]{8}{*}{ Group 2} & Odontoma & $10(52.6)$ & $9(47.4)$ & $19(100)$ & 0.575 \\
\hline & Ossifying fibroma & $11(61.1)$ & $7(38.9)$ & $18(100)$ & 0.717 \\
\hline & Ameloblastoma & $4(44.4)$ & $5(55.6)$ & $9(100)$ & 0.376 \\
\hline & Cementoma & $1(50.0)$ & $1(50.0)$ & $2(100)$ & 0.822 \\
\hline & Adenomatoid odontogenic tumor & $2(100)$ & $0(0)$ & $2(100)$ & 0.217 \\
\hline & Odontogenic myxoma & $1(100)$ & $0(0)$ & $1(100)$ & 0.387 \\
\hline & Ameloblastic fibroma & $1(100)$ & $0(0)$ & $1(100)$ & 0.387 \\
\hline & Total & $30(57.7)$ & $22(42.3)$ & $52(100)$ & 0.688 \\
\hline \multirow[t]{11}{*}{ Group 3} & Giant cell granuloma & $21(60.0)$ & $14(40.0)$ & $35(100)$ & 0.252 \\
\hline & Pyogenic granuloma & $13(86.7)$ & $2(13.3)$ & $15(100)$ & 0.066 \\
\hline & Osteoma & $11(78.6)$ & $3(21.4)$ & $14(100)$ & 0.295 \\
\hline & Benign fibro-osseous lesion & $2(66.7)$ & $1(33.3)$ & $3(100)$ & 0.744 \\
\hline & Fibrous dysplasia & $1(50.0)$ & $1(50.0)$ & $2(100)$ & 0.612 \\
\hline & Brown tumor & $0(0)$ & $2(100)$ & $2(100)$ & 0.108 \\
\hline & Osteomyelitis & $1(100)$ & $0(0)$ & $1(100)$ & 0.477 \\
\hline & Florid osseous dysplasia & $1(100)$ & $0(0)$ & $1(100)$ & 0.477 \\
\hline & Benign spindle cell tumor & $0(0)$ & $1(100)$ & $1(100)$ & 0.155 \\
\hline & Lymphangioma & $0(0)$ & $1(100)$ & $1(100)$ & 0.155 \\
\hline & Total & $50(66.7)$ & $25(33.3)$ & $75(100)$ & 0.140 \\
\hline \multirow[t]{5}{*}{ Group 4} & Squamous cell carcinoma & $3(60.0)$ & $2(40.0)$ & $5(100)$ & 0.850 \\
\hline & Malignant melanoma & $1(100)$ & $0(0)$ & $1(100)$ & 0.408 \\
\hline & Mucinous adenocarcinoma & $0(0)$ & $1(100)$ & $1(100)$ & 0.168 \\
\hline & Osteosarcoma & $1(100)$ & $0(0)$ & $1(100)$ & 0.408 \\
\hline & Total & $5(62.5)$ & $3(37.5)$ & $8(100)$ & 0.410 \\
\hline
\end{tabular}

Values are presented as number $(\%)$.

Hatice Hosgor et al: Evaluation of biopsies of oral and maxillofacial lesions: a retrospective study. J Korean Assoc Oral Maxillofac Surg 2019 
Table 2. Distributions of groups by age

\begin{tabular}{|c|c|c|c|c|}
\hline & Lesion & Age range (yr) & Mean $\pm S D(y r)$ & $P$-value \\
\hline \multirow[t]{6}{*}{ Group 1} & Radicular cyst & $8-88$ & $38.75 \pm 15.29$ & 0.157 \\
\hline & Dentigerous cyst & $9-71$ & $40.61 \pm 15.41$ & $0.042 *$ \\
\hline & Odontogenic keratocyst & $15-66$ & $46.36 \pm 17.37$ & 0.814 \\
\hline & Nasopalatine duct cyst & $17-83$ & $46.36 \pm 17.97$ & 0.112 \\
\hline & Lateral periodontal cyst & $27-49$ & $38.00 \pm 15.55$ & 0.971 \\
\hline & Total & $8-88$ & $39.60 \pm 15.47$ & 0.297 \\
\hline \multirow[t]{8}{*}{ Group 2} & Odontoma & $10-70$ & $27.36 \pm 19.68$ & 0.277 \\
\hline & Ossifying fibroma & $13-64$ & $36.44 \pm 15.20$ & 0.259 \\
\hline & Ameloblastoma & $20-72$ & $43.33 \pm 17.64$ & 0.141 \\
\hline & Cementoma & $43-61$ & $52.00 \pm 12.72$ & 0.080 \\
\hline & Adenomatoid odontogenic tumor & $14-16$ & $15.00 \pm 1.41$ & 0.960 \\
\hline & Odontogenic myxoma & 57 & 57 & 0.080 \\
\hline & Ameloblastic fibroma & 12 & 12 & 0.999 \\
\hline & Total & $10-72$ & $34.01 \pm 18.61$ & $0.031 *$ \\
\hline \multirow[t]{11}{*}{ Group 3} & Giant cell granuloma & $7-84$ & $43.05 \pm 20.74$ & 0.158 \\
\hline & Pyogenic granuloma & $28-63$ & $47.06 \pm 20.74$ & $0.025 *$ \\
\hline & Osteoma & $13-62$ & $41.00 \pm 13.98$ & 0.697 \\
\hline & Benign fibro-osseous lesion & $32-48$ & $38.00 \pm 8.71$ & 0.891 \\
\hline & Fibrous dysplasia & $22-50$ & $36.00 \pm 19.79$ & 0.148 \\
\hline & Brown tumor & $10-13$ & $11.50 \pm 2.12$ & 0.150 \\
\hline & Osteomyelitis & 62 & 62 & 0.999 \\
\hline & Florid osseous dysplasia & $22-50$ & $36.00 \pm 19.79$ & 0.999 \\
\hline & Benign spindle cell tumor & 19 & 19 & 0.753 \\
\hline & Lymphangioma & 38 & 38 & 0.976 \\
\hline & Total & $7-84$ & $42.29 \pm 17.81$ & 0.281 \\
\hline \multirow[t]{5}{*}{ Group 4} & Squamous cell carcinoma & $50-86$ & $68.60 \pm 15.42$ & 0.438 \\
\hline & Malignant melanoma & 55 & 55 & 0.753 \\
\hline & Mucinous adenocarcinoma & 80 & 80 & 0.238 \\
\hline & Osteosarcoma & 13 & 13 & 0.238 \\
\hline & Total & $13-86$ & $61.37 \pm 23.72$ & 0.331 \\
\hline
\end{tabular}

(SD: standard deviation)

$* P<0.05$

Hatice Hosgor et al: Evaluation of biopsies of oral and maxillofacial lesions: a retrospective study. J Korean Assoc Oral Maxillofac Surg 2019

cyst, 23 cases $(6.8 \%)$ of odontogenic keratocyst, 22 cases $(6.5 \%)$ of nasopalatine duct cysts, and two cases $(0.6 \%)$ of lateral periodontal cysts. One hundred sixty-nine of the cysts involved the maxilla (49.7\%), while 171 were present in the mandible (50.3\%). The most commonly affected sites were the mandibular posterior region $(\mathrm{n}=128 ; 37.6 \%)$ and maxillary anterior region $(\mathrm{n}=128 ; 37.6 \%)$, followed by the mandibular anterior region $(n=43 ; 12.6 \%)$ and maxillary posterior region ( $\mathrm{n}=41 ; 12.1 \%)$.(Table 3 ) Overall, radicular cyst was the most frequent type observed in group 1 . The mean age of patients in this group was $38.75 \pm 15.29$ years (range, $8-88$ years) and the female:male ratio was 1:2. Radicular cysts were most commonly observed in the maxillary anterior region and secondly in the mandibular posterior region.

In group 2 , odontoma $(n=19 ; 36.5 \%)$ was the most frequent odontogenic tumor of the 52 cases, followed by ossifying fibroma $(n=18 ; 34.6 \%)$, ameloblastoma $(n=9 ; 17.3 \%)$, cementoma $(n=2 ; 3.8 \%)$, adenomatoid odontogenic tumor $(n=2$; $3.8 \%)$, odontogenic myxoma $(\mathrm{n}=1 ; 1.9 \%)$, and ameloblastic fibroma $(n=1 ; 1.9 \%)$. Thirty cases $(57.7 \%)$ of odontogenic tumors were in the mandible and 22 cases $(42.3 \%)$ were in the maxilla. The most affected site was the mandibular posterior region $(\mathrm{n}=23 ; 44.2 \%)$, followed by the maxillary posterior region $(n=14 ; 26.9 \%)$, maxillary anterior region $(n=8 ; 15.4 \%)$, and mandibular anterior region $(n=7 ; 13.5 \%)$.(Table 3$)$ The mean age among the odontoma cases, which was the most frequent odontogenic tumor, was 27.3 \pm 19.6 years (range, 1070 years), and the female:male ratio was 10:9. Odontomas were seen equally in the mandibular posterior and maxillary posterior regions.

In group 3, 35 (46.7\%) of the 75 cases were giant cell granuloma, followed by 15 cases $(20.0 \%)$ of pyogenic granuloma; 14 cases (18.7\%) of osteoma; and 11 cases (14.7\%) of other lesions including benign fibro-osseous lesions $(n=3 ; 4.0 \%)$, fibrous dysplasia $(n=2 ; 2.7 \%)$, brown tumor $(n=2 ; 2.7 \%)$, osteomyelitis $(n=1 ; 1.3 \%)$, florid osseous dysplasia $(n=1 ; 1.3 \%)$, benign spindle cell tumor $(\mathrm{n}=1 ; 1.3 \%)$, and lymphangioma $(\mathrm{n}=1 ; 1.3 \%)$. Bone tumor and related lesions were seen in 47 cases $(62.7 \%)$ in the mandible and 28 cases $(37.3 \%)$ in the maxilla. The most affected site was the mandibular posterior region ( $\mathrm{n}=29 ; 38.7 \%)$, followed by the maxillary posterior region $(n=20 ; 26.7 \%)$, mandibular anterior region $(n=18$; 
Table 3. Distributions of groups by anatomical location of the lesion

\begin{tabular}{|c|c|c|c|c|c|c|}
\hline & Lesion & $\begin{array}{l}\text { Maxillary } \\
\text { anterior }\end{array}$ & $\begin{array}{c}\text { Maxillary } \\
\text { posterior }\end{array}$ & $\begin{array}{c}\text { Mandibular } \\
\text { anterior }\end{array}$ & $\begin{array}{c}\text { Mandibular } \\
\text { posterior }\end{array}$ & $P$-value \\
\hline \multirow[t]{6}{*}{ Group 1} & Radicular cyst & $96(44.4)$ & $26(12.0)$ & $37(17.1)$ & $57(26.4)$ & $0.000 *$ \\
\hline & Dentigerous cyst & $9(11.7)$ & $15(19.5)$ & $1(1.3)$ & $52(67.5)$ & $0.000 *$ \\
\hline & Odontogenic keratocyst & $1(4.3)$ & $0(0)$ & $4(17.4)$ & $18(78.3)$ & $0.000 *$ \\
\hline & Nasopalatine duct cyst & $22(100)$ & $0(0)$ & $0(0)$ & $0(0)$ & $0.000 *$ \\
\hline & Lateral periodontal cyst & $0(0)$ & $0(0)$ & $1(50.0)$ & $1(50.0)$ & 0.347 \\
\hline & Total & $128(37.6)$ & $41(12.1)$ & $43(12.6)$ & $128(37.6)$ & $0.000 *$ \\
\hline \multirow[t]{8}{*}{ Group 2} & Odontoma & $5(26.3)$ & $6(31.6)$ & $2(10.5)$ & $6(31.6)$ & 0.279 \\
\hline & Ossifying fibroma & $1(5.6)$ & $7(38.9)$ & $4(22.2)$ & $6(33.3)$ & 0.139 \\
\hline & Ameloblastoma & $0(0)$ & $1(11.1)$ & $0(0)$ & $8(88.9)$ & $0.029 *$ \\
\hline & Cementoma & $0(0)$ & $0(0)$ & $1(50.0)$ & $1(50.0)$ & 0.398 \\
\hline & Adenomatoid odontogenic tumor & $1(50.0)$ & $0(0)$ & $0(0)$ & $1(50.0)$ & 0.480 \\
\hline & Odontogenic myxoma & $1(100)$ & $0(0)$ & $0(0)$ & $0(0)$ & 0.132 \\
\hline & Ameloblastic fibroma & $0(0)$ & $0(0)$ & $0(0)$ & $1(100)$ & 0.733 \\
\hline & Total & $8(15.4)$ & $14(26.9)$ & $7(13.5)$ & $23(44.2)$ & 0.111 \\
\hline \multirow[t]{11}{*}{ Group 3} & Giant cell granuloma & $3(8.6)$ & $9(25.7)$ & $12(34.3)$ & $11(31.4)$ & 0.254 \\
\hline & Pyogenic granuloma & $3(20.0)$ & $3(20.0)$ & $6(40.0)$ & $3(20.0)$ & 0.137 \\
\hline & Osteoma & $0(0)$ & $6(42.9)$ & $0(0)$ & $8(57.1)$ & $0.027 *$ \\
\hline & Benign fibro-osseous lesion & $1(33.3)$ & $0(0)$ & $0(0)$ & $2(66.7)$ & 0.293 \\
\hline & Fibrous dysplasia & $0(0)$ & $0(0)$ & $0(0)$ & $2(100)$ & 0.353 \\
\hline & Brown tumor & $1(50.0)$ & $1(50.0)$ & $0(0)$ & $0(0)$ & 0.196 \\
\hline & Osteomyelitis & $0(0)$ & $0(0)$ & $0(0)$ & $1(100)$ & 0.658 \\
\hline & Florid osseous dysplasia & $0(0)$ & $0(0)$ & $0(0)$ & $1(100)$ & 0.658 \\
\hline & Benign spindle cell tumor & $0(0)$ & $0(0)$ & $0(0)$ & $1(100)$ & 0.658 \\
\hline & lymphangioma & $0(0)$ & $1(100)$ & $0(0)$ & $0(0)$ & 0.426 \\
\hline & Total & $8(10.7)$ & $20(26.7)$ & $18(24.0)$ & $29(38.7)$ & 0.201 \\
\hline \multirow[t]{5}{*}{ Group 4} & Squamous cell carcinoma & $1(20.0)$ & $1(20.0)$ & $0(0)$ & $3(60.0)$ & 0.221 \\
\hline & Malignant melanoma & $0(0)$ & $1(100)$ & $0(0)$ & $0(0)$ & 0.386 \\
\hline & Mucinous adenocarcinoma & $1(100)$ & $0(0)$ & $0(0)$ & $0(0)$ & 0.180 \\
\hline & Osteosarcoma & $0(0)$ & $1(100)$ & $0(0)$ & $0(0)$ & 0.386 \\
\hline & Total & $2(25.0)$ & $3(37.5)$ & $0(0)$ & $3(37.5)$ & 0.280 \\
\hline
\end{tabular}

$* P<0.05$.

Values are presented as number $(\%)$.

Hatice Hosgor et al: Evaluation of biopsies of oral and maxillofacial lesions: a retrospective study. J Korean Assoc Oral Maxillofac Surg 2019

$24.0 \%)$, and maxillary anterior region $(n=8 ; 10.7 \%)$.(Table 3$)$

The most frequent lesion in this group was giant cell granuloma, and the mean age of these patients was $43.05 \pm 20.74$ years (range, 7-84 years), with a female:male ratio of 3:2. Giant cell granulomas were seen most commonly in the mandibular anterior region and secondly in the mandibular posterior region.

Finally, in group 4 , five $(62.5 \%)$ of the eight cases were squamous cell carcinoma (SCC), followed by one case $(12.5 \%)$ of malign melanoma, one case $(12.5 \%)$ of mucinous adenocarcinoma, and one case $(12.5 \%)$ of osteosarcoma. Malignant tumors of the jaw were seen in five cases $(62.5 \%)$ involving the maxilla and thee cases (37.5\%) involving the mandible. The maxillary posterior region and the mandibular posterior region were affected equally. The most frequent type of lesion in this group was SCC. The mean age of patients was $68.6 \pm 15.42$ years (range, $50-86$ years), and the female:male ratio was 3:2. SCC was most commonly seen in the mandibular posterior region, while the maxillary anterior and maxillary posterior regions were affected equally.(Table 3 )

\section{Discussion}

OMF lesions can cause many pathological changes in the hard and soft tissues of affected regions. The prevalence and incidence of these lesions may vary according to age, sex, and location of the pathology; knowledge of these factors can aid in identifying the lesion type and informing the patients correctly. However, these factors alone are often not enough for clear determination of the lesion; clinical and radiological examination, biopsy, and histopathological examination are crucial for final diagnosis and treatment planning.

In the literature, OMF lesion names, groups, and subtypes have changed regularly since Broca ${ }^{5}$ first described them in 1868. The first edition of histological classification of odontogenic tumors was published by the WHO in 1971 and has been revised three times to date ${ }^{6}$. In particular, there were five major changes in the new classification released in 2017 compared with the third version from $2005^{1}$ : odontogenic cysts, which were not included in the previous classifications, are classified mainly based on their true nature ${ }^{2}$; odontogenic 
keratocyst and calcifying odontogenic cyst were removed from classification of odontogenic tumors and were included instead in classification of odontogenic cysts ${ }^{3}$; new entities such as sclerosing odontogenic carcinoma and primordial odontogenic tumor were identified ${ }^{4}$; ameloblastic fibrodentinoma, ameloblastic fibro-odontoma, and odontoameloblastoma were removed from the classification scheme entirely ${ }^{5}$; and osseous dysplasia and ossifying fibroma were renamed as cemento-osseous dysplasia and cemento-ossifying fibroma ${ }^{7}$.

In the present study, the most common group of lesions was odontogenic cysts $(71.6 \%)$, followed by bone tumors and related lesions $(15.8 \%)$, odontogenic tumors $(10.9 \%)$, and malignant tumors of the jaw (1.7\%). According to a study by Jaafari-Ashkavandi and Akbari ${ }^{8}$ conducted in Iran, the odontogenic cyst group (63\%) was the most common, followed by groups of benign bone pathologies (15.9\%), odontogenic tumors $(11.9 \%)$, and malignant tumors of the jaw (2.8\%) and these results were very similar to those in our study. Separately, in a prior retrospective study conducted in Turkey, cystic lesions were found to compose $17.13 \%$, benign tumor and related lesions composed $8.25 \%$, malignant tumors composed $1.72 \%$, inflammatory and reactive lesions composed $35.69 \%$ and other lesions composed $37.2 \%$ of the total findings ${ }^{9}$.

Tekkesin et al. ${ }^{10}$ evaluated 5,088 odontogenic and nonodontogenic cyst cases and reported that the most common cyst present was the radicular cyst, followed by the odontogenic keratocyst and dentigerous cyst, and these authors claimed that Turkish populations have high risk of aggressive cysts because of the more frequent appearance of the odontogenic keratocyst than the dentigerous cyst. Another study conducted in the southeast region of Turkey showed that $63 \%$ of the cysts were reported as radicular cysts, $26.9 \%$ as dentigerous cysts, $6.1 \%$ as odontogenic keratocysts, $3.4 \%$ as residual radicular cysts, and $0.6 \%$ as nasopalatine cysts ${ }^{11}$. The most frequent cyst observed was the radicular cyst $(63.5 \%)$, followed by the dentigerous cyst $(22.6 \%)$ and the odontogenic keratocyst $(6.7 \%)$ in the present study. de Souza et al. ${ }^{12}$ found that the most frequent odontogenic cysts in their investigation were radicular cysts $(61.4 \%)$, followed by dentigerous cysts (20.1\%) and odontogenic keratocysts (6.4\%), showing similar results to those of our research.

Age is one of the major factors for the distribution of odontogenic cysts and the distribution pattern of odontogenic cysts can change with age. In our study, the mean age of patients was $39.6 \pm 15.47$ years. In the study of Tekkesin et al. ${ }^{10}$, also conducted in Turkey, the mean age was 36.33 years, while, in another study ${ }^{12}$ performed in the Brazilian population, the mean age of patients was 31 years.

In the present study, cysts were found in men (69.7\%) more frequently than in women $(30.3 \%)$. Similar results were found among studies conducted in our country but to a rate that was less than $69.7 \%$, even though the incidence remained higher in males. In the study by Tekkesin et al. ${ }^{10}$, cysts were more common in male patients $(57.7 \%)$ according to 5,088 biopsies, and Açıkgöz et al. ${ }^{13}$ also reported a male predominance $(53.8 \%)$ in their study involving a Turkish population.

In this study, 169 cysts were located in the maxilla (49.7\%) and 171 were located in the mandible $(50.3 \%)$, with the most affected sites being the mandibular posterior region $(\mathrm{n}=128$; $37.6 \%)$ and maxillary anterior region $(n=128 ; 37.6 \%)$, followed by mandibular anterior region $(n=43 ; 12.6 \%)$, and maxillary posterior region $(n=41 ; 12.1 \%)$. Radicular cysts more often affected the maxillary anterior region, while dentigerous cysts and odontogenic keratocyst were more commonly observed in the mandibular posterior region, similar to in other reports in the literature ${ }^{10-14}$.

Members of the odontogenic tumor group composed $10.9 \%$ of cases among all biopsies in the present study. In the literature, it was reported that odontogenic tumor rates range from $1.2 \%$ to $2.5 \%$ of all biopsies across studies, a ratio that is less than that in our research ${ }^{15-17}$. The main reason for this difference may be exclusion of soft tissue reactive lesions and inflammatory processes in this study.

The most frequent odontogenic tumors were, in order, odontoma (36.5\%), cemento-ossifying fibroma (34.6\%), ameloblastoma (17.3\%), adenomatoid odontogenic tumor $(3.8 \%)$, cementoma $(3.8 \%)$, odontogenic myxoma (1.9\%), and ameloblastic fibroma (1.9\%) in the present study. As previously mentioned, odontogenic keratocyst was considered a cyst according to the second edition of the WHO classification, while it was regarded as a tumor in the third edition. In the fourth edition published in 2017, odontogenic keratocyst was described as a cyst again, and this modification likely influences the rankings of odontogenic tumors in the literature. According to Jaeger et al. ${ }^{18}$, odontoma (39.67\%) was the most common odontogenic tumor, similar to in our research, when odontogenic keratocyst was defined as a cyst. However, when it was described as an odontogenic tumor, the most common tumor was the keratocystic odontogenic tumor (41.07\%); in this situation, the ratio of odontogenic tumors to all pathologies increased from 2.04 to $11.51 \%$ in their study. In a multicentric retrospective study of 2,000 cases in the Turkish population, the keratocystic odontogenic tumor (classified as a tumor at the time) was the most frequent finding 
(57.2\%), followed by odontoma (16.7\%) and ameloblastoma $(15.08 \%)^{19}$. In another study ${ }^{20}$ conducted in Turkey, ameloblastoma (36.5\%) was reported as the most common tumor, followed by odontoma (18\%) and cementoma (15\%). However, the incidence of aggressive tumors such as ameloblastoma is much higher in African countries. According to Akinmoladun et al. ${ }^{21}$, whose study was conducted in Nigeria, 1,754 ameloblastomas were reported among 3,075 cases (57.04\%), while, in the study by Adebayo et al..$^{22}$, cases of ameloblastoma composed $73 \%$ of all tumors. Thus, in studies conducted in Africa ${ }^{21,22}$, the frequency of ameloblastoma is significantly higher in comparison with other regions of the world, including Turkey. This may be due to limited health care services in countries with populations of lower socioeconomic levels, for which people can only receive health care after emergence of severe symptoms, and routine treatment is not often available to catch signs and symptoms early ${ }^{23}$.

According to Jing et al. ${ }^{24}$, the age of patients with odontogenic tumors varied from three to 84 years with a mean age of 32.1 years, while, in Turkey, Sekerci et al. ${ }^{25}$ reported that the age of their patients ranged from 10 to 84 years, with a mean age of 34.52 years. These results are very similar to those in our study; we reported a mean age of $34.01 \pm 18.61$ years in patients with odontogenic tumor.

In the present study, odontogenic tumors were reported in women $(57.7 \%)$ more frequently than in men (42.3\%). Olgac et al. ${ }^{26}$ reported that odontogenic tumors were seen in female patients $(53 \%)$ more so than in male patients $(47 \%)$ in Turkey, which is similar to in our study. According to another study $^{25}$ conducted in our country, a slight predominance of afflicted males (50.5\%) was reported, but this result was not statistically significant.

Odontogenic tumors in the study of Jing et al. ${ }^{24}$ were observed in $75.5 \%$ of all mandibular jaw cases in China, while another study in Turkey ${ }^{25}$ reported $77.9 \%$ of such cases in the mandible. In the present study, the most typically affected site was the mandibular posterior region $(44.2 \%)$, followed by the maxillary posterior region (26.9\%), maxillary anterior region (15.4\%), and mandibular anterior region (13.5\%), similar to other studies.

The bone tumors and related lesions group included 15.8\% of all pathologies in the present study. Of the 75 cases, $46.7 \%$ were giant cell granuloma; $20 \%$ were pyogenic granuloma; $18.7 \%$ were osteoma; and $14.6 \%$ were other lesions including fibrous dysplasia, osteomyelitis, florid osseous dysplasia, brown tumor, lymphangioma, and benign spindle cell tumor. According to Jaafari-Ashkavandi and Akbari ${ }^{8}$, benign bone pathologies were the second most common lesions $(15.9 \%$ of all lesions) after odontogenic cysts, and central giant cell granuloma was the most common lesion of all benign bone pathologies. However, some researchers reported odontogenic tumors more frequently than benign bone pathologies in their study populations ${ }^{27,28}$. In the study of Jaafari-Ashkavandi and Akbari ${ }^{8}$, ossifying fibroma was accepted as a benign bone lesion, while we included it in the odontogenic tumor group as cemento-ossifying fibroma, based on the fourth edition of the WHO classification ${ }^{7}$. In our study, if ossifying fibroma had been included in the bone tumors and related lesions group, the incidence among all pathologies would have increased from $15.7 \%$ to $19.5 \%$.

As indicated above, the most frequent type of lesion among bone tumors and related lesions was giant cell granuloma, with a mean age of affected patients of 43.05 years (range, 7-84 years). Of this subpopulation of 35 cases, 21 (60.0\%) were female and $14(40.0 \%)$ were male. In the Boffano et al.'s study ${ }^{29}$, the mean age of patients with peripheral giant cell granuloma was 48.8 years (range, $8-89$ years), and the lesions showed female preponderance $(62.3 \%)$. Although the sex distribution of such lesions between their study and ours was fairly equal, the lesion appeared more often in older patients in our study. In the literature, peripheral giant cell granuloma has been seen more commonly in the mandible than the maxilla ${ }^{30}$. However, the maxilla was involved in $50.6 \%$, and the mandible affected $49.4 \%$ of about 874 cases in the Boffano et al.'s study ${ }^{29}$. In that study, giant cell granuloma was reported at $65.7 \%$ ( $\mathrm{n}=23$ cases) in the mandible and $34.3 \%$ ( $\mathrm{n}=12$ cases) in the maxilla; the most affected region was the mandibular anterior region ( $\mathrm{n}=12$ cases), followed by the mandibular posterior region ( $\mathrm{n}=11$ cases). However, in our study, we did not describe giant cell granulomas as either central or peripheral giant cell granulomas, so it is not possible to make a precise comparison.

In the present study, cases of malignant tumors of the jaw were observed as $1.7 \%$ (in eight cases) of all pathologies, with the most frequent lesion being $\mathrm{SCC}$ ( $\mathrm{n}=5$ cases), while osteosarcoma, mucinous adenocarcinoma, and malign melanoma were reported in one case each. In a multicenter study in Turkey, $0.37 \%$ of the tumors were malignant ${ }^{19}$. Malignant tumors of the jaw were reported to range from $2.1 \%$ to $5.4 \%$ in other countries ${ }^{8,31,32}$. Surprisingly, the incidence of malignant tumors here was low compared with other studies, although Kocaeli is a region with a high rate of cancer. Although the cancer population is high in Kocaeli, the reason for the lower incidence of malignant tumors could be ex- 
plained as the presentation of patients firstly to ear, nose, and throat clinics. Our patients in this group were encountered during the initial examination.

SCC was the most frequent malignant lesion in this study, reported as $62.5 \%$ of all malignant tumors, and the mean age of patients was 68.6 years. In the study of $\mathrm{Tay}^{32}$, SCC constituted $67 \%$ of all malignant lesions, similar to our research. However, in the study of Jaafari-Ashkavandi and Akbari ${ }^{8}$, osteosarcoma (28.1\%) was the most frequent malignant tumor. Oral SCC is seen mostly in the older patient population; in our study, the mean age of the SCC population was 68.6 years. However, the incidence of oral malignant tumors has been increasing among the young population in recent years. Almoznino et al. ${ }^{31}$ reported five SCC patients under the age of 30 years. In the present study, malignant tumors affected mostly the mandibular posterior region ${ }^{33}$, and SCC was reported in three of five cases with posterior mandibular involvement.

\section{Conclusion}

In this article, 475 biopsy results obtained from the maxillofacial region were evaluated based on the fourth edition of the WHO classification, and noted changes in the incidence of lesions due to age, sex, and geographic differences were compared with those in the literature. Evaluation of data for correct diagnosis and treatment planning of OMF pathologies is crucial. However, only the results of biopsies by our department were reported in the study; to adequately determine the prevalence and incidence of OMF lesions, biopsies performed by other specialists such as otolaryngologists and plastic surgeons performing biopsies in the OMF regions should also be evaluated. Further, more extensive studies are needed with larger patient series.

\section{ORCID}

Hatice Hosgor, https://orcid.org/0000-0002-6925-9526

Berkay Tokuc, https://orcid.org/0000-0002-1149-2886

Bahadır Kan, https://orcid.org/0000-0001-6980-2085

Fatih Mehmet Coskunses, https://orcid.org/0000-0001-8764-5992

\section{Authors' Contributions}

All authors participated in data collection and H.H. and B.T. wrote the manuscript. All authors read and approved the final manuscript.

\section{Ethics Approval and Consent to Participate}

The study was approved by the Clinical Research Ethics Committee of Kocaeli University (KÜ GOKAEK 2018/151), and the written informed consent was obtained from all patients.

\section{Conflict of Interest}

No potential conflict of interest relevant to this article was reported.

\section{References}

1. Bataineh AB, Rawashdeh MA, Al Qudah MA. The prevalence of inflammatory and developmental odontogenic cysts in a Jordanian population: a clinicopathologic study. Quintessence Int 2004;35:815-9.

2. Parkins GE, Armah G, Ampofo P. Tumours and tumour-like lesions of the lower face at Korle Bu Teaching Hospital, Ghana--an eight year study. World J Surg Oncol 2007;5:48.

3. Mosqueda-Taylor A. New findings and controversies in odontogenic tumors. Med Oral Patol Oral Cir Bucal 2008;13:E555-8.

4. El-Naggar AK, Chan JKC, Grandis JR, Takata T, Slootweg PJ. WHO classification of head and neck tumours. 4th ed. Lyon: International Agency for Research on Cancer (IARC); 2017:204-60.

5. Broca P. Invesitgations into a new group of tumours known as odontomes. Gaz Hebd Sci Med 1868;5:70.

6. Hong SP, Ellis GL, Hartman KS. Calcifying odontogenic cyst. A review of ninety-two cases with reevaluation of their nature as cysts or neoplasms, the nature of ghost cells, and subclassification. Oral Surg Oral Med Oral Pathol 1991;72:56-64.

7. Speight PM, Takata T. New tumour entities in the 4th edition of the World Health Organization Classification of Head and Neck tumours: odontogenic and maxillofacial bone tumours. Virchows Arch 2018;472:331-9.

8. Jaafari-Ashkavandi Z, Akbari B. Clinicopathologic study of intraosseous lesions of the Jaws in Southern Iranian population. J Dent (Shiraz) 2017;18:259-64.

9. Şimsek Ş, Öner B, Şimsek B, Barıș E, Üstay C. A retrospective evaluations of the biopsies of the lesions of the oral and maxillofacial region in Gazi university faculty of dentistry department of oral and maxillofacial surgery. Turkiye Klinikleri J Dental Sci 2004; 10:85-9.

10. Tekkesin MS, Olgac V, Aksakalli N, Alatli C. Odontogenic and nonodontogenic cysts in Istanbul: analysis of 5088 cases. Head Neck 2012;34:852-5.

11. Demirkol M, Ege B, Yanik S, Aras MH, Ay S. Clinicopathological study of jaw cysts in southeast region of Turkey. Eur J Dent 2014;8:107-11.

12. de Souza LB, Gordón-Núñez MA, Nonaka CF, de Medeiros MC, Torres TF, Emiliano GB. Odontogenic cysts: demographic profile in a Brazilian population over a 38-year period. Med Oral Patol Oral Cir Bucal 2010;15:e583-90.

13. Açikgöz A, Uzun-Bulut E, Özden B, Gündüz K. Prevalence and distribution of odontogenic and nonodontogenic cysts in a Turkish population. Med Oral Patol Oral Cir Bucal 2012;17:e108-15.

14. Hwang DS, Kim YH, Kim UK, Ryu MH, Kim GC. Retrospective clinical study of multiple keratocystic odontogenic tumors in non-syndromic patients. J Korean Assoc Oral Maxillofac Surg 2018;44:107-11. 
15. Daley TD, Wysocki GP, Pringle GA. Relative incidence of odontogenic tumors and oral and jaw cysts in a Canadian population. Oral Surg Oral Med Oral Pathol 1994;77:276-80.

16. Mosqueda-Taylor A, Ledesma-Montes C, Caballero-Sandoval S, Portilla-Robertson J, Ruíz-Godoy Rivera LM, Meneses-García A. Odontogenic tumors in Mexico: a collaborative retrospective study of 349 cases. Oral Surg Oral Med Oral Pathol Oral Radiol Endod 1997;84:672-5.

17. Buchner A, Merrell PW, Carpenter WM. Relative frequency of central odontogenic tumors: a study of 1,088 cases from Northern California and comparison to studies from other parts of the world. J Oral Maxillofac Surg 2006;64:1343-52.

18. Jaeger F, de Noronha MS, Silva ML, Amaral MB, Grossmann SM, Horta MC, et al. Prevalence profile of odontogenic cysts and tumors on Brazilian sample after the reclassification of odontogenic keratocyst. J Craniomaxillofac Surg 2017;45:267-70.

19. Gültekin SE, Sengüven B, Barış E, Özer Yücel Ö, Tekkeşin MS, Günhan Ö, et al. Odontogenictumours: a multicentric retrospective study of 2000 cases in Turkish population. Oral Surg Oral Med Oral Pathol Oral Radiol 2015;119:e188.

20. Günhan O, Erseven G, Ruacan S, Celasun B, Aydintug Y, Ergun E, et al. Odontogenic tumours. A series of 409 cases. Aust Dent J 1990;35:518-22.

21. Akinmoladun VI, Udeabor SE, Arotiba JT. Pattern of odontogenic tumours in Nigeria: a review of the literature. Niger Dent $\mathrm{J}$ 2010;18:212-6.

22. Adebayo ET, Ajike SO, Adekeye EO. A review of 318 odontogenic tumors in Kaduna, Nigeria. J Oral Maxillofac Surg 2005;63:811-9.

23. Simon EN, Merkx MA, Vuhahula E, Ngassapa D, Stoelinga PJ. A 4-year prospective study on epidemiology and clinicopathological presentation of odontogenic tumors in Tanzania. Oral Surg Oral Med Oral Pathol Oral Radiol Endod 2005;99:598-602.

24. Jing W, Xuan M, Lin Y, Wu L, Liu L, Zheng X, et al. Odontogenic tumours: a retrospective study of 1642 cases in a Chinese population. Int J Oral Maxillofac Surg 2007;36:20-5.

25. Sekerci AE, Nazlim S, Etoz M, Deniz K, Yasa Y. Odontogenic tumors: a collaborative study of 218 cases diagnosed over 12 years and comprehensive review of the literature. Med Oral Patol Oral Cir Bucal 2015;20:e34-44.

26. Olgac V, Koseoglu BG, Aksakalli N. Odontogenic tumours in Istanbul: 527 cases. Br J Oral Maxillofac Surg 2006;44:386-8.

27. Ali MA. Biopsied jaw lesions in Kuwait: a six-year retrospective analysis. Med Princ Pract 2011;20:550-5.

28. Dhanuthai K, Banrai M, Limpanaputtajak S. A retrospective study of paediatric oral lesions from Thailand. Int J Paediatr Dent 2007; 17:248-53.

29. Boffano P, Benech R, Roccia F, Gallesio C, Garzaro M, Pecorari G. Review of peripheral giant cell granulomas. J Craniofac Surg 2013;24:2206-8.

30. Giansanti JS, Waldron CA. Peripheral giant cell granuloma: review of 720 cases. J Oral Surg 1969;27:787-91.

31. Almoznino G, Zadik Y, Vered M, Becker T, Yahalom R, Derazne $\mathrm{E}$, et al. Oral and maxillofacial pathologies in young- and middleaged adults. Oral Dis 2015;21:493-500.

32. Tay AB. A 5-year survey of oral biopsies in an oral surgical unit in Singapore: 1993-1997. Ann Acad Med Singapore 1999;28:665-71.

33. Vadillo RM, Contreras SJ, Canales JO. Prognostic factors in patients with jaw sarcomas. Braz Oral Res 2011;25:421-6.

How to cite this article: Hosgor $\mathrm{H}$, Tokuc B, Kan B, Coskunses

FM. Evaluation of biopsies of oral and maxillofacial lesions:

a retrospective study. J Korean Assoc Oral Maxillofac Surg

2019;45:316-323. https://doi.org/10.5125/jkaoms.2019.45.6.316 